\title{
Una experiencia ecuménica
}

\section{An ecumenical experience}

\author{
María Silvia Di Liscia \\ Professora associada del Departamento de Historia/Universidad Nacional de La Pampa \\ silviadi@fchst.unlpam.edu.ar
}

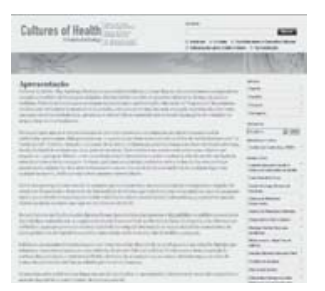

CULTURES of Health: a Historical Anthology.

Coordenação de Steven

Palmer. Desenvolvido

pela Canada Research

Chair in History of

International Health,

Department of History,

University of Windsor.

Disponível em:

http://hih.uwindsor.ca/

wordpress/index.php/

mission-statement/.

Acesso em: 22 fev.

2010.

inversión de tiempo y esfuerzo. Su principal realizador es el coordinador del Department of History, Steven Palmer. No se restringe a comunicaciones de un país/territorio ni de un período histórico determinado. Po eso, resulta de gran interés para los latinoamericanos puesto que proporciona la posibilidad de estar en permanente contacto con la producción de investigadores de otras partes del mundo, de épocas muy diversas y especialistas en temáticas muy específicas.

Las ventajas pueden no ser evidentes a primera vista ya que la parcialidad de los aportes en un país o en los límites de una época resultan difíciles de evaluar en un primer momento dada la celeridad que se le exige a la necesidad de ampliar los conocimientos. Esta globalización real, planteada de manera consciente por Culturas de la Salud, tal como lo define su coordinador en la invitación a quienes deseen publicar sus textos con la sola limitación de hacerlos en virtud de su pertenencia histórica, tiene por objetivo hacer aportes que se consideren de carácter sociocultural en la complejidad histórica de la salud. Se trata entonces de colocar (o 'colgar', como vulgarmente se dice en español) documentos, minidocumentales, videos, gráficos, fotos e imágenes, mapas y todo otro tipo de textos para que sean compartidos por investigadores, especialistas o simplemente interesados de 
todo el mundo. La búsqueda de 'fragmentos' de trabajos completos apunta a una exposición más fluida, con un destino que no sea solamente el de las reuniones académicas usuales o de la publicación para un público cada vez más selecto y recortado.

La apuesta es ser parte de una 'experiencia ecuménica' e implica más que la suma de todos los aportes, ya que los debates continúan en los foros y comentarios. La babel lingüística tiene un lugar en la página: puede publicarse en inglés, francés, portugués y español. Los enlaces remiten a libros, otros sitios (Canada Research Chair in History of International Healt, Casa Oswaldo Cruz, Health Heritage Research Services, Médicament: object social, entre las varias opciones), a publicaciones de referencia indispensable para el mundo hispano y anglosajón (Asclepio; Bulletin of the History of Medicine; Canadian Bulletin of Medical History; Dynamis: Acta Hispanica; História, Ciências, Saúde - Manguinhos; Historiae Medicinae; Isis; Journal of the History of Medicine and Allied Sciences; Medical History; Social History of Medicine; $y$ Salud Colectiva, entre otras) y a asociaciones de interés.

Con un diseño atractivo y un navegador amigable, es posible, por ejemplo, ingresar a través de la ya mítica imagen del Jeca Tatu - la personificación del atrasado Brasil del interior - a las nociones desgranadas por los médicos de principios de siglo. La forma en que se presenta la también clásica noción del gigante país latinoamericano como no sólo un espacio de riquezas sin fin sino como un preocupante e inmenso hospital, también lo hace muy atractivo. Son de asombrarse los panfletos publicados en Ontario, entre 1920 y 1930, como campaña publicitaria del Departamento de Salud para incentivar la vacunación antidiftérica. En uno de ellos, se dibuja el nacimiento de un 'super bebé', monstruoso en su tamaño, que representa gráficamente las aspiraciones eugenésicas sobre el futuro de la raza blanca. Y más recientemente, Cultures of Health se ha hecho también un espacio para recoger cuestiones de mayor actualidad, como supone el impacto de la Gripe A (H1N1) en México, en relación con su significado social y cultural y los cambios en la vida cotidiana y la interrelación siempre presente entre enfermedad, política e historia. Finalmente, como se invita desde los primeros momentos, la participación de más interesados con materiales diferentes permitirá construir un tipo de conocimiento distinto al que depende de la circulación - ya electrónica o en papel - de artículos y libros de la especialidad. ¿Cuáles son los peligros de estas formas de comunicación? Podemos citar dos: la banalidad de las temáticas y su recorte excesivo y resumido. Sin embargo, las ganancias son mucho mayores: la posibilidad de una casi instantánea consulta, la fluidez de los textos y una distribución del conocimiento, sin perder el rigor académico. En última instancia, una posibilidad más democrática de acceso hacia otros lenguajes, centros e investigadores, que es lo que ha soñado más de un investigador desde la invención de la imprenta.

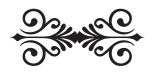

